\title{
UNIFICAÇÃO DAS RESPONSABILIDADES CONTRATUAL E EXTRACONTRATUAL: TENDÊNCIA OU FICÇÃO?
}

\section{Tonison Rogério Chanan ${ }^{1}$}

Resumo: Este artigo propõe uma análise da unificação da responsabilidade civil contratual e extracontratual. Classifica-se como uma pesquisa bibliográfica e documental, utilizou-se o método de abordagem dialético. Apontou-se as lacunas existentes no sistema atual de responsabilidade vigente no Brasil, e uma breve análise comparada com outros países. Discorreu-se sobre as teorias existentes: monista, dualista e eclética, demonstrando as razões que justificam cada tese, e contrapondo suas diferenças. Abordou-se sobre a jurisprudência brasileira com relação a prescrição, bem como procedeu-se ponderações acerca da possibilidade de unificação, e qual seria a vantagem de se ter um sistema único de responsabilidade civil.

Palavras-chave: Responsabilidade Civil. Contratual. Extracontratual. Unificação.

\section{UNIFICATION OF CONTRACTUAL AND EXTRA-CONTRACTUAL LIABILITY: TREND OR FICTION?}

\begin{abstract}
This article proposes an analysis of the unification of contractual and noncontractual civil liability. It's classified as a bibliographical and documentary research, using the method of dialectical approach. The shortcomings in the current accountability system in Brazil were pointed out, and a brief analysis compared with other countries. It was discussed the existing theories: monistic, dualistic and eclectic, demonstrating the reasons that justify each thesis, and counterposing their differences. Brazilian jurisprudence was discussed with regard to prescription, as well as considerations about the possibility of unification, and what would be the advantage of having a unique system of civil liability.
\end{abstract}

Keywords: Civil Liability. Contractual and Non-Contractual Civil liability. Unification of Theories.

\section{INTRODUÇÃO}

\footnotetext{
${ }^{1}$ Advogado e Professor das disciplinas de Direito de Obrigações, Contratos e Direito do Consumidor na UNIBAVE e UNISUL. Pós Graduado em Curso de Especialização em Direito Empresarial e Civil pela Academia Brasileira de Direito Constitucional - ABDConst. Pós Graduado em Curso de Especialização em Direito Contratual pela Escola Paulista de Direito - EPD. Mestrando em Direito pela Pontifícia Universidade Católica do Rio Grande do Sul. Área de Concentração: Fundamentos Constitucionais do Direito Público e do Direito Privado. Endereço postal: Travessa Manoel Pinho, 61, Centro, Laguna/SC, CEP. 88.790-000. E-mail: tonisonchanan@gmail.com
}

Revista Brasileira de Direito Civil em Perspectiva | e-ISSN: 2526-0243| Porto Alegre | v. 4 | n. 2 |

p. 79-101 | Jul/Dez. 2018 
A discussão acerca da unificação dos institutos de responsabilidade civil contratual e extracontratual não é nova, e cada vez mais escutam-se vozes de estudiosos, tanto no Brasil como no exterior, que a tese monista é uma tendência a ser seguida.

No Brasil, como na maioria dos países que foram influenciados pelo Direito Romano, impera o sistema dualista de responsabilidade civil, por exemplo, Portugal, Espanha, França, Argentina, são alguns dos países que também adotam este modelo, ou seja, diferenciase a responsabilidade advinda pela prática de um delito para com a responsabilidade oriunda do descumprimento de uma convenção realizada entre as partes.

Ambos os institutos possuem fundamentação própria no Código Civil brasileiro (2002), com requisitos e características distintas muito bem definidas, o que se percebe com uma simples consulta à codificação. A responsabilidade pelo inadimplemento contratual está positivada nos artigos 389 a 405, ao passo que a responsabilidade extracontratual ou delitual, também conhecida por responsabilidade aquiliana possui fundamento nos artigos 186, 187, 188 em conjunto com os artigos 927 a 954, do mesmo diploma.

Assim, tem-se a bipartição da responsabilidade civil: a contratual, advinda do descumprimento de um negócio jurídico e a extracontratual, oriunda de ato ou omissão que fere o dever imposto pela lei.

Ressalta o professor francês Eric Savaux (2001, p. 01) que deve ser evitada qualquer ambiguidade, pois a pretensão da unificação da responsabilidade civil, não resultará no abandono da responsabilidade contratual, muito menos deve ser cogitada a ideia de liberação do devedor frente as suas obrigações, o estudo se propõe a analisar a possiblidade de ambas responsabilidades serem regidas por um modelo único.

Assim, o presente artigo abordará as lacunas existentes no sistema atual de responsabilidade civil vigente no Brasil, e apresentará uma breve análise de direito comparado. Depois serão apresentadas as teorias existentes: monista, dualista e eclética, demonstrando as razões que justificam cada tese, e contrapondo suas diferenças. Por fim, mostrar-se-á o comportamento da jurisprudência brasileira com relação a prescrição, com breves ponderações acerca da possibilidade de unificação, e qual seria a vantagem de se ter um sistema único de responsabilidade civil.

Revista Brasileira de Direito Civil em Perspectiva | e-ISSN: 2526-0243| Porto Alegre | v. 4 | n. 2 |

p. 79-101 | Jul/Dez. 2018 


\section{RESPONSABILIDADE CIVIL NO CONTEXTO ATUAL}

$\mathrm{Na}$ doutrina nacional, há muito tempo discute sobre o tema de se criar um modelo único de responsabilidade, conforme se infere das palavras de Pontes de Miranda (1966, t. LIII, p. 186) proferidas em meados do século passado:

"É possível, portanto, esperar-se que se apaguem as distinções entre a responsabilidade delitual e a responsabilidade negocial, de modo que se crie, por sobre elas, mais solidamente, outro sistema, unitário, de reparação fundada na culpa ou em equilíbrio material de posições jurídicas".

Apesar de a tese unitária de responsabilidade não ter sido adotada pelo Código Civil em sua última reforma no ano de 2002, é possível perceber sua presença com o advento do Código de Defesa do Consumidor, desde o início da década de 90. Em matéria de relação de consumo, não se faz qualquer distinção entre responsabilidade contratual ou extracontratual, não se faz análise da presença dos requisitos necessários para se apurar a responsabilidade aquiliana, tais como: nexo de causalidade, por exemplo.

O Código de Defesa do Consumidor não apresenta qualquer distinção acerca das modalidades delitual ou contratual, e prevê nos artigos 12 a 14 a responsabilidade pelo fato do produto e da prestação do serviço. Também prevê no artigo 18 a 20 a responsabilidade pelo vício de qualidade, quantidade do produto e do serviço prestado, respectivamente.

Com efeito, no âmbito da Relação de Consumo, até mesmo o terceiro vítima do evento danoso será equiparado a condição de Consumidor e terá plena legitimidade para pleitear indenização em desfavor do fabricante, produtor, construtor, seja nacional ou estrangeiro, bem como do importador, mesmo que não tenha participado diretamente da relação contratual, adquirindo bens ou utilizando serviços.

No exemplo acima citado, não se analisa o vínculo jurídico negocial existente entre as partes, vítima e ofensor, tampouco se perquiri acerca da presença do nexo causal, o que demonstra que a responsabilidade que permeia o Código Consumerista é geneticamente modificada, assim por dizer, ou seja, é autêntica e não deve ser confundida com a responsabilidade contratual ou extracontratual previstas no ordenamento civil.

Revista Brasileira de Direito Civil em Perspectiva | e-ISSN: 2526-0243| Porto Alegre | v. 4 | n. 2 |

p. 79-101 | Jul/Dez. 2018 
O resultado da criação de uma responsabilidade inovadora e unitária no sistema consumerista é digna de elogios, pois contempla uma gama de situações cotidianas em um microssistema simples e de fácil intelecção aos olhos do consumidor. Esta sensação de satisfação não se restringe apenas na alma do consumidor, mas também permeia a prática processual, otimizando o trabalhado dos operadores da justiça de forma indistinta.

A pergunta que sobrevém a mente é: Seria possível unificar ou até mesmo criar um sistema de responsabilidade legal e inédito, de forma semelhante ao previsto na legislação consumerista, para aplicação no ordenamento civil?

Sem dúvida é uma proposta desafiadora, a qual poderia trazer benefícios semelhantes aos experimentados pela Codificação Consumerista, e suprir largas lacunas existentes no ordenamento civil, como por exemplo, ao se apurar a responsabilidade na "fase de puntuação" ou "negociações preliminares".

Até mesmo no cotidiano jurídico, é possível perceber alguns deslizes técnicos em petições, que fundamentam as perdas e danos oriundas de um descumprimento contratual, ou sentenças que realizam a entrega da tutela jurisdicional de inadimplemento contratual, com base no artigos 186 e 927, como se o comando do artigo 389, todos do Código Civil, não fosse o suficiente e não suprisse o desejo de alicerçar o pleito de condenação em danos emergentes e/ou lucros cessantes.

É possível perceber de forma cristalina, na redação do referido artigo 389, que o devedor ao descumprir obrigação será responsabilizado por eventuais perdas e danos que causar, acrescidos dos encargos moratórios, despesas processuais e honorários advocatícios. Por sua vez, o instituto das perdas e danos possui previsão no artigo 402 do Código Civil, e abrangem tanto o dano emergente, como os lucros cessantes. Deste modo, seria despiciendo fundamentar o direito a reparação de perdas e danos advindos de um descumprimento contratual, com base no artigo 186 e 927, ambos do Código Civil.

Contudo, a questão da correta fundamentação da responsabilidade contratual em peças jurídicas pode ser vista como mero capricho do operador do direito, e não resplandece uma discussão profunda da temática posta a apreciação, mas apenas demonstra eventual desconfiança ou insegurança jurídica, de que o comando legal possa lhe garantir o resultado útil da consequência das perdas e danos, que é a sua reparação.

Revista Brasileira de Direito Civil em Perspectiva | e-ISSN: 2526-0243| Porto Alegre | v. 4 | n. 2 |

p. 79-101 | Jul/Dez. 2018 
Talvez hoje, a maior lacuna a ser suprimida, enquanto vigente o sistema de responsabilidade dualista, é como fundamentar as perdas e danos advindos da "fase de puntuação" ou das "negociações preliminares", momento este designado de "quase delito" ou “quase contrato", em razão da culpa in contrahendo.

Novamente ressurge a problematização, a culpa in contrahendo deve ser enquadrada sob o aspecto da responsabilidade contratual ou extracontratual? A escolha da regência como sendo delitual ou negocial, implicará, por exemplo, no marco inicial da fluência de juros, pois se fundada em matéria contratual os juros terão fluência da data da citação, com base no artigo 405 do Código Civil, se regimentada sob a tutela da responsabilidade delitual, os juros terão fluência desde a data do evento danoso, a teor do artigo 398 do mesmo diploma.

Rudolph von Ihering foi pioneiro ao estudar a responsabilidade pré-contratual, por meio da publicação em 1861, do artigo: "Culpa in contrahendo: indenização em contratos nulos ou não chegados à perfeição", inspirado no espírito que norteara o Corpus Juris de Justiniano (JACOB, 1997, p. 175).

A descoberta de Ihering gerou repercussão no meio jurídico, e a doutrina alemã interpretou a culpa in contrahendo à luz do $\mathrm{BGB}^{2}$, a qual percebeu que haveria elementos para imposição de uma obrigação geral de correção nas tratativas. (FRANZ apud JACOB, p. 176)

No Brasil, o debate iniciou após ter transcorrido quase um século de discussão na Europa, e a primeira abordagem foi realizada por Antônio Chaves, em 1959. E foi elogiada por Couto e Silva, o qual considerava a teoria uma notável descoberta no campo da dogmática jurídica (JACOB, 1997, p. 175), pois graças à pesquisa de Von Ihering, novos e modernos conceitos foram trazidos ao Direito das Obrigações.

É possível identificar casos intrigantes sobre a responsabilidade e a aplicação da teoria da culpa in contrahendo ou responsabilidade pré-contratual na jurisprudência portuguesa (MENEZES CORDEIRO, 2000, p. 397-398) desde a década de 60:

“26-set-1961: uma pessoa penetra num supermercado aberto ao público; escorrega numa casca de banana e fere-se; o dono do local é condenado por falta de segurança pré-contratual".

\footnotetext{
${ }^{2}$ Acrônimo utilizado para referenciar Bürgerliches Gesetzbuch, que significa Código Civil em Alemão, que entrou em vigor em $1^{\circ}$ de janeiro de 1900.
}

Revista Brasileira de Direito Civil em Perspectiva | e-ISSN: 2526-0243| Porto Alegre | v. 4 | n. 2 | 
“07-fev-1964: uma empresa realiza um concurso para a seleção de um trabalhador especialmente qualificado; é escolhida uma candidata, combinando-se uma data para a sua apresentação ao serviço e para a celebração formal do contrato de trabalho; a interessada falta e desrespeita outras datas depois acordadas, acabando por esclarecer que, por razões de saúde, nunca poderia aceitar o lugar em jogo; é condenada por não ter, desde o início, dado essa informação: inutilizou, com o seu silêncio, todo um concurso". (Tratado de Direito Civil Português, págs. 397 e 398).

Vislumbra-se que o primeiro caso faz referência a prestação de um serviço, e mesmo que não tenha sido realizada compra no supermercado, ou seja, ainda que o consumidor tenha adentrado ao estabelecimento comercial apenas para fins de especulação de preço, já estava implícito o dever de segurança, o que caracteriza o quase delito ou o quase contrato.

Já o segundo caso trata do dever de informação, é certo e não se nega o direito da candidata de não aceitar a oferta de emprego, contudo, não soa como justo que alguém abra diálogo por livre e espontânea vontade e nutra um sentimento de esperança a outra pretensa parte contratante, lhe cause prejuízos, e que em momento posterior, rompa as tratativas, por motivo que já era de sua prévia convicção, mas omite de prestar tal informação.

Quaisquer dos casos acima espelham o tema deste debate, e vestem como luvas ao questionamento anteriormente realizado: A fundamentação da responsabilidade deverá ser calcada nos princípios do direito contratual ou da responsabilidade delitual?

Tem-se que os casos de responsabilidade pré-contratual atualmente estão situados numa fase nebulosa, onde não é possível enxergar com clareza se estão sedimentados em território de natureza delitual ou negocial.

A jurisprudência nacional já enfrentou o tema em discussão, sendo que o caso de maior repercussão é o "caso dos tomates”, ocorrido no Rio Grande do Sul.

Os fatos são os seguintes: um agricultor do município de Canguçu, na zona sul do estado do Rio Grande do Sul, costumava plantar tomates, cujas sementes lhe eram entregues pela CICA (Companhia Industrial de Conservas Alimentícias), na qual, à época oportuna, adquiria a produção, para posterior industrialização. Na safra de 1987/1988, a CICA deixou de adquirir o produto, tendo o agricultor, como de praxe, realizado a plantação. Fato este que motivou o agricultor a pleitear indenização pelos danos sofridos com a perda da produção, uma vez que não teve a quem vender o produto. (RIO GRANDE DO SUL, 1991)

Revista Brasileira de Direito Civil em Perspectiva | e-ISSN: 2526-0243| Porto Alegre | v. 4 | n. 2 |

p. 79-101 | Jul/Dez. 2018 
Na época o Desembargador Relator Ruy Rosado de Aguiar Júnior, reconheceu que a CICA havia criado expectativas nos possíveis contratantes, pecando contra a boa-fé, ao se recusar a comprar a safra dos tomates, ocasionando prejuízo aos pequenos agricultores, que tinham se baseado na confiança despertada antes do contrato, na fase pré-contratual.

Consideram que, em casos semelhantes aos acima expostos, a responsabilidade é tida como contratual, com forte na doutrina italiana: Ruy Rosado de Aguiar Júnior (1991, p. 245), Carlyle Popp (2001, p. 150), Antônio Junqueira de Azevedo (1995, p. 131), entre outros.

O saudoso professor Antônio Junqueira de Azevedo (1995, p. 123-124), explica de forma minuciosa a razão pela qual a responsabilidade pré-contratual merece tratamento sob a perspectiva da responsabilidade contratual em detrimento da responsabilidade delitual:

\begin{abstract}
"Pessoalmente, tendo em vista nossa idéia de que o contrato é um processo (uma sucessão de 'tempos', como ocorre com o próprio negócio jurídico), que vai, desde a fase pré-contatual, passando à fase contratual, distribuída em três fases menores (conclusão do contrato, eficácia do contrato e execução/adimplemento do contrato), e indo até a fase pós-contratual, todas subordinadas à boa-fé objetiva, pensamos que, embora surgindo de ato ilícito, a responsabilidade pré-contratual, por se tratar de deveres específicos, gerados pela boa-fé objetiva, deva se submeter ao tratamento da responsabilidade contratual $[\ldots]$ "..'
\end{abstract}

O enquadramento como responsabilidade pré-contratual, resulta do fato de que o respeito ao princípio contratual da boa-fé objetiva se faz presente em todas as fases do contrato, desde a fase de negociação/especulação, passando pela sua conclusão e cumprimento, até mesmo após a sua extinção - fase pós-contratual. Por esta razão, o fato que ensejou eventual dano, ainda que tenha sido causado em momento anterior a conclusão/assinatura do contrato deve ser abarcado pelas regras de direito contratual.

No julgamento do Recurso Especial n ${ }^{\circ}$ 1367955, o Ministro do Superior Tribunal de Justiça, Paulo de Tarso Sanseverino, em acórdão de sua relatoria esclarece que: "por opção legislativa, a responsabilidade civil pré-contratual tem natureza contratual, haja vista o art. 422 do Código Civil estar inserido no Título V ("Dos Contratos em Geral”), e não no Título III, referente aos atos ilícitos.” (BRASIL, 2015)

A omissão na redação do artigo 422 do Código Civil (2002), que deixou de contemplar o dever expresso dos contraentes de agir de acordo com os princípios da boa-fé, 
na fase pré e pós-contratual contribui para a discussão, pois da simples dicção do artigo, haveria dever tão somente com relação a fase da conclusão e seu cumprimento.

Esta omissão foi debatida na Jornada de Direito Civil (2012, p. 19) e resultou na edição dos Enunciado n 24, que dispõe: “Em virtude do princípio da boa-fé, positivado no art. 422, a violação dos deveres anexos constitui espécie de inadimplemento, independentemente de culpa". E também pelo Enunciado n”. 25: "O art. 422 do Código Civil não inviabiliza a aplicação, pelo julgador, do princípio da boa-fé nas fases pré e póscontratual".

Neste mesmo sentido é o Projeto de Lei $n^{\circ}$ 6960/2002, de autoria do Deputado Federal Ricardo Fiuza, que visa alterar o art. 422 do Código Civil, que passaria a ter a seguinte redação:

\footnotetext{
"Os contraentes são obrigados a guardar, assim nas negociações preliminares e conclusão do contrato, como em sua execução e fase pós-contratual, os princípios da boa-fé e tudo mais que resulte da natureza do contrato, da lei, dos usos e das exigências da razão e da equidade."
}

Como descrito, na culpa in contrahendo, há violação dos deveres laterais à boa-fé objetiva, entre os quais se destacam: a lealdade, a assistência, a diligência, a segurança, a consideração com o outro, o dever de informação e o de probidade, entre outros.

Régis Fichtner Pereira (2001, p. 94), acrescenta que o dever de lealdade é inerente as negociações e que sua violação enseja a responsabilidade pré-negocial:

“[...] quando o sujeito inicia as tratativas mesmo sem o real interesse de contratar, ou se abandona abrupta e injustificadamente as negociações, quando criou na contraparte a legítima expectativa de que ocorreria a conclusão do negócio jurídico. Isso, porque o outro sujeito pode inclusive ter incorrido em despesas, já que confiava na formação do contrato."

É certo que nem todo rompimento de tratativa engendrará o dever de reparação na fase pré-negocial, é preciso ter cautela ao se analisar o direito de indenização. Ademais, gizese que a fase de puntuação em regra não gera obrigações, em razão de seu eminente caráter especulativo, aliado a prevalência da vontade de não contratar, o qual configura exercício regular de um direito.

Revista Brasileira de Direito Civil em Perspectiva | e-ISSN: 2526-0243| Porto Alegre | v. 4 | n. 2 |

p. 79-101 | Jul/Dez. 2018 
Deste modo, para caracterizar o dever de reparação devem estar configurados alguns requisitos na relação pré-contratual: a) afronta à boa-fé objetiva e à dignidade da pessoa humana; b) existência de consentimento prévio ao início das tratativas; c) rompimento ilegítimo das tratativas, ou seja, sem justa causa; d) ocorrência de prejuízo; e) a relação de causalidade entre a ruptura das tratativas e o dano sofrido.

Em contrapartida aqueles que defendem que na fase de puntuação ou pré-contratual a responsabilidade é aquiliana, consideram o rompimento imotivado das tratativas como um ato ilícito, em razão de que o ato praticado pela parte desistente estará revestido de dolo, negligência ou imprudência. Maria Helena Diniz (2012, p. 62) conclui ainda, que não haverá a opção de exigir o cumprimento futuro do contrato, apenas de pleitear a reparação do dano pelas normas que regem a culpa extracontratual.

Compartilham deste mesmo entendimento Judith Martins Costa, Caio Mário da Silva Pereira, Pontes de Miranda, Carvalho Mendonça e Orlando Gomes, entre outros autores (PEREIRA, 2001, p. 149).

Rui Stoco (2011, p. 165-166) argumenta que se deve ter "em mente, porém, que a responsabilidade extracontratual e a contratual regulam-se racionalmente pelos mesmos princípios, porque a ideia de responsabilidade, como já enfatizado, é una."

Entretanto, a dialética travada vai além dos campos do enquadramento como um delito civil ou da configuração de uma responsabilidade negocial, e se exterioriza, ainda que de forma minoritária, como um tertium genus. Régis Fichtner Pereira (2001, p. 149) entende não haver uma natureza específica para a responsabilidade pré-negocial, pois esta não possui nem natureza contratual, nem extracontratual, sendo, assim, necessário construir um sistema para que se atenda às suas peculiaridades.

Em razão deste conflito doutrinário, a tese da unificação da responsabilidade pode se revelar como uma aparente solução para esta lacuna, razão pela qual passa-se a analisar os argumentos que sustentam a teoria monista.

\section{DIFERENTES REGIMES DE RESPONSABILIDADES}

Revista Brasileira de Direito Civil em Perspectiva | e-ISSN: 2526-0243| Porto Alegre | v. 4 | n. 2 |

p. 79-101 | Jul/Dez. 2018 
A discussão em tela não é revestida de inovação, pois sua problemática foi descartada em mesa a mais de um século, contudo, se tornou mais clarividente após o sistema único de responsabilidade civil adotado pelo Código de Defesa do Consumidor a quase três décadas, e que tem representado satisfação no meio jurídico, o que torna a discussão acerca de qual teoria seria mais benéfica a se adotar atraente e o ascende a um grau de evidencia nos manuais que tratam do tema de obrigação e responsabilidade.

\subsection{TEORIA MONISTA}

A teoria monista foi lapidada por Lefebvre no ano de 1896, e logo depois desenvolvida e apresentada por Grandmoulin, criticando a ideia de dualidade de culpas, pois só existe uma - a culpa de natureza delitual, conforme exposto na obra de Mario Castillo Freyre e Verônica Rosas Berastain (2014, p. 53), que:

"[...] el primero de los autores sustentó su planteamiento criticando la idea de dualidad de culpas y aduciendo que aquélla es sólo una y posse natureza delictual.

Grandmoulin, por su parte, fundamentó su postura alegando que no existe diferencia alguna entre la ley y el contrato, puesto que la ley es un contrato público em tanto emana del acuerdo de voluntades individuales que forman el Estado, y el contrato es una ley entre las partes. Em ambos casos la responsabilidad surgiría del incumplimiento de una obligación preexistente, por lo que infiere que no hay dos tipos de responsabilidad, sino una sola que es delictual por implicar una infracción a la ley."

Verifica-se, assim, que o pilar de sustentação da tese monista, é baseado na inexistência de diferença entre Lei e o Contrato, posto que a Lei é um contrato público, o qual emana do acordo de vontades individuais que formam o Estado.

Os estudiosos adeptos da unificação afirmam que a responsabilidade civil é só uma, pois todos os casos de responsabilidade advém de um proceder contralegem, e que por isso o ordenamento jurídico deve contemplar um regime único. Em sentido semelhante é a tese aventada pelos irmãos franceses Mazeaud, segundo os quais:

“[...] de acordo com a tese tradicional, consagrada pela codificação francesa, quando surge a responsabilidade contratual, já existe um vínculo jurídico entre o agente e sua vítima. Ambos são partes de um contrato e é justamente porque uma delas não o executou, que a questão é de responsabilidade

Revista Brasileira de Direito Civil em Perspectiva | e-ISSN: 2526-0243| Porto Alegre | v. 4 | n. 2 |

p. $79-101 \mid$ Jul/Dez. 2018 
contratual. Uma tal responsabilidade é somente a sanção de uma obrigação preexistente e, como tal, impotente para criar uma obrigação. Já quando da responsabilidade extracontratual, nenhum vínculo jurídico existe entre o autor do dano e sua vítima antes que os princípios da responsabilidade extracontratual entrem em jogo. São eles que criam este vínculo: a responsabilidade extracontratual é, assim, uma fonte de obrigações ao mesmo título que o contrato." (BECKER, 2010, p. 357)

Para os irmãos Mazeaud, o argumento dualista para justificar uma oposição profunda entre as duas espécies de responsabilidade, pelo fato de que uma provém de um ato lícito pelo acordo de vontades, e a outra por um ato ilícito, em razão do descumprimento da lei, não se sustenta, pela razão de que:

“[...] estas duas obrigações sucessivas são, ao menos teoricamente, bem distintas uma da outra, mesmo que uma seja sequência da outra e que não se possa conceber sem a primeira, pois se a primeira nasce da vontade das partes, a segunda existe fora dela:" é contra a vontade do inadimplente que ele se torna devedor de perdas e danos, cujo montante é determinado conforme as regras legais. Desta forma, a responsabilidade contratual é, ao mesmo título que extracontratual, fonte de obrigação e, por isso, por advir da violação do contrato, é também ela originária de ato ilícito e, portanto, em ambos os casos, a responsabilidade nasce da inexecução de uma obrigação preexistente.” (BECKER, 2010, p. 358)

Nota-se que a explicação dos irmãos Mazeaud, não se restringe em afirmar numa visão simplista de que ambas responsabilidades estão calcadas na lei, mas que as obrigações que resultam da infração à lei e da violação de um contrato apresenta sempre a mesma estrutura e são polarizadas pela mesma finalidade, a satisfação do interesse do credor. (BECKER, 2010, p. 359)

Naturalmente, a ideia lançada inicialmente por Lefebvre, de que a Lei é um contrato público, vez que emana do acordo de vontades individuais que formam o Estado, possibilitou a primeira noção de que vivemos em sociedade.

O direito ganhou uma nova perspectiva com a interdisciplinaridade, que possibilita uma comunicação da ciência jurídica com outras ciências, este sadio diálogo permite que o jurista possa compreender fenômenos estudados por outras ciências, mas que influenciam diretamente no campo jurídico, como por exemplo, tecnologia, medicamentos, comportamento social, o que permite a revisão de velhos paradigmas e nos possibilita um estudo mais acurado sob uma nova perspectiva.

Revista Brasileira de Direito Civil em Perspectiva | e-ISSN: 2526-0243| Porto Alegre | v. 4 | n. 2 |

p. 79-101 | Jul/Dez. 2018 
A teoria tridimensional do direito de Miguel Reale, também resplandece traços de interdisciplinaridade, segundo a qual o Direito é fato, valor e norma, os problemas sociais demandam que o aplicador do Direito seja um sociólogo - do ponto de vista dos fatos: um filósofo - na perspectiva dos valores; e um jurista - na análise das normas. (CARVALHO, 2015, p. 201- 212)

Também, sob a influência da interdisciplinaridade, permitiu que Clóvis Veríssimo do Couto e Silva difundisse no Brasil e aplica-se ao direito a sistematização apresentada pelo sociólogo alemão Leopold von Wiese, de contato social:

\begin{abstract}
"Que conceitua a relação social como um corte estático na trama da interação humana e o processo social como um movimento desta trama, as relações sociais são o resultado de processos sociais de aproximação ou de afastamento entre os indivíduos. A sociedade é uma textura de relações inter-pessoais, uma série de processos de aproximação ou distanciamento entre os indivíduos. A relação social é, assim, uma posição instável de união ou separação entre os humanos, originada por um processo social consistente em movimentos de aproximação e distanciamento. E todas as relações, tanto associativas como dissociativas, iniciam-se por meio de contatos sociais, embora nem todo contato dê origem a um processo." (BECKER, 2010, p. 361)
\end{abstract}

A ideia do sociólogo alemão ingressa no mundo jurídico, na medida em que a convivência da vida em sociedade nos permite uma inegável relação sociável, a qual por vezes pode ser mais próxima ou mais distante. Isto porque, o contato social é o pressuposto para desencadear todo e qualquer processo social.

A base de sua premissa é o processo social, pois existem processos sociais de aproximação ou afastamento que podem dar origem a uma nova relação, ou seja, a um processo por meio do contato das pessoas. Nem todo contato social será fruto de um processo, pois por vezes o contato pode ser tão distante ou fugaz que não possibilite a criação de uma relação jurídica, sendo que contatos mais duradouros e permanentes possam originar uma relação negocial ou até mesmo responsabilidade delitual, no caso de um agir contralegem.

É neste ponto que convergem a ideia de unificação da responsabilidade, pois haveria um ponto de nascimento comum entre as duas espécies de responsabilidades, ao apontar a própria vida em sociedade como a mais ampla e originária de todas as outras fontes. (BECKER, 2010, p. 361)

Revista Brasileira de Direito Civil em Perspectiva | e-ISSN: 2526-0243| Porto Alegre | v. 4 | n. 2 |

p. 79-101 | Jul/Dez. 2018 
E a classificação de fontes jurídicas defendida por Pontes de Miranda reforça ainda mais a ideia de aceitação da relação social como nascente de todas as responsabilidades, vez que a seu ver as fontes jurídicas variam conforme a amplitude com que o ordenamento valoriza a manifestação de vontade das partes expressa no ato. (BECKER, 2010, p. 362)

O diálogo realizado entre a sociologia e o direito permite concluir que toda relação jurídica, seja lícita ou ilícita, é considerada uma relação social, mas nem todas relação social é um relação jurídica, de forma que os contatos mais distantes, como simples fato de viver em sociedade, conduzirão à responsabilidade extracontratual, e as formas mais próximas, como contrato, determinarão a responsabilidade contratual. (BECKER, 2010, p. 362)

O professor francês Eric Savaux (2001, p. 130), aponta a tese de Albert Brun, que possui fundamento diverso dos irmãos Mazeaud, em razão de que ambas responsabilidades são mecanismos de mesma natureza, pois as diferenças de regime que as opõe, são fundadas essencialmente sobre a originalidade do fato gerador, a qual em matéria contratual a inexecução de uma obrigação decorre da convenção, e não da lei.

Em comentário a Teoria do Processus Social, Emilio Betti enfatiza que, com relação à responsabilidade pré-negocial esvaziam-se por completo a discussão no que tange a sua natureza jurídica, e que adotar uma ou outra solução é mera questão de gosto, situando-se a diferença, sobretudo na carga da prova, que no fundo reflete a verdadeira situação da atual distinção entre os dois tipos de responsabilidade. (BECKER, 2010, p. 371)

\subsection{TEORIA DUALISTA}

Alguns autores apontam que a divisão existente entre a responsabilidade contratual e extracontratual se deve em razão do Direito Romano, pois enquanto a Lei das XII Tábuas, datada do ano de 452 a.C., se propunha a aplicar ao delito a pena de talião, "olho por olho, dente por dente" e tinha aplicação precípua a poucos tipos de contratos, como por exemplo: compra e venda, locação, empréstimo e sociedade; por sua vez a Lex Aquilia, que vigorou a partir do ano de 286 a.C., possuía como escopo a aplicação do adágio neminem laedere, no qual a ninguém é facultado causar prejuízo a outrem, dando assim origem ao que conhecemos hoje por responsabilidade extracontratual ou aquiliana. (SILVA, 2005, p. 72)

Revista Brasileira de Direito Civil em Perspectiva | e-ISSN: 2526-0243| Porto Alegre | v. 4 | n. 2 |

p. 79-101 | Jul/Dez. 2018 
Por este motivo, a Legislação Justiniana, que vigorou em 528/534 a.C., manteve o tratamento diferenciado aos dois institutos de responsabilidade, e apresentou como as fontes das obrigações: o contrato, o delito, o quase-contrato e o quase-delito. (SILVA, 2005, p. 72)

A título de exemplo, pela notória importância do Código Civil Francês ao mundo jurídico, no ano de 1804, abordou-se a responsabilidade através de um duplo regime, partindo da ideia de dualidade do conceito de culpa, um culpa contratual e outro extracontratual, apesar de que atualmente se reconhece a unidade de culpa, mas o regime duplo de responsabilidade se mantém. (CASIELLO, 1989, p. 912)

O tratadista belga Sainctelette, no ano de 1884, foi o primeiro a assinalar as diferenças existentes entre o sistema de responsabilidade negocial e delitual, e concluiu que as diferenças apontadas eram irredutíveis, tendo em vista que as relações jurídicas entre os sujeitos de direito podem ser reguladas pela lei ou pelo contrato, enquanto o contrato assimila um dever de acordo motivado pelo interesse particular, sendo que a lei pressupõe uma atenção a ordem pública. (CASIELLO, 1989, p. 912)

Sem emissão de juízo de valor de modo a favorecer a escolha de que a tese monista ou dualista seria a melhor solução a se seguir, há de se reconhecer que a tomada de decisão deve ocorrer somente após esgotados todos os debates e encontradas soluções para as diferenças acessórias que cada instituto amalga.

Vencida a etapa de distinção e origem de Fontes, dada a peculiaridade de cada instituto, é possível apontar algumas diferenças primordiais de cada espécie de responsabilidade, sem, contudo, a intenção de solucionar o imbróglio.

a) Capacidade civil: na relação contratual não é possível se sustentar uma relação jurídica entre absolutamente incapazes, enquanto na responsabilidade delitual, a capacidade envolvida é muito mais ampla de modo que permite imputar ao menor incapaz a responsabilidade de reparar o dano com bens de seu patrimônio, caso configure a exceção de que o responsável não disponha de meios suficientes;

b) Gradação da culpa: em sede de responsabilidade contratual não se permite perquirir acerca da elasticidade da culpa, na responsabilidade aquiliana é possível fazer sua gradação em culpa, levíssima, leve, grave ou gravíssima;

Revista Brasileira de Direito Civil em Perspectiva | e-ISSN: 2526-0243| Porto Alegre | v. 4 | n. 2 |

p. 79-101 | Jul/Dez. 2018 
c) Mora: o marco inicial que junge a incidência de juros moratórios no contrato, em regra, dá-se à partir da citação (Art. 405/CC), e prevalece a regra de se proceder a constituição em mora do devedor, o que pode ser realizado por meio de uma interpelação/notificação judicial ou extrajudicial, com exceção dos casos em que prevalece a cláusula resolutiva expressa (Arts. 474 e 135/CC). Em contrapartida, a responsabilidade aquiliana não necessita a constituição do devedor em mora, pois os juros fluem da data do ato ilícito (Art. 398/CC);

d) Extensão da Reparação: a quebra imotivada de contratos em regra não admite dano moral; bem como a indenização em razão da prática de infração pode sofrer limitações ao valor estipulado a título de Cláusula Penal; nos contratos paritários há possibilidade de se limitar os riscos transformando em alternativa ao credor a opção de executar o valor disposto na Cláusula Penal ou propor ação ordinária para reaver prejuízo em valor maior (Art. 410/CC); ou ainda dispõe o contratante a possibilidade de convencionar cláusula de indenização suplementar, (Art. 416/CC). Enquanto a responsabilidade aquiliana compreende todo dano sofrido, (Art. 402/CC);

e) Ônus da prova: em matéria de direito contratual basta o credor comprovar a existência da obrigação, sendo que para exigir a pena convencional não é necessário que se alegue prejuízo (Art. 416/CC) Não há, portanto, necessidade de se comprovar a culpa da parte infratora, o que se exterioriza numa presunção jure et de jure. Já em matéria de responsabilidade civil extracontratual, a regra geral é que a vítima que reclama a indenização deve provar o fato doloso ou culposo do causador do dano;

f) Resultado das obrigações: em matéria de contrato boa parte das obrigações são de fim ou de resultado, exemplo: contratos de compra e venda, de locação, de construção civil. Em matéria de responsabilidade aquiliana, a maioria das obrigações são consideradas como de meio, exemplo: o dever de socorrer uma vítima para não configurar omissão de socorro;

g) Competência: tratando-se de direito contratual, em regra, é o lugar em que o negócio foi proposto, salvo convenção em contrário. Já em relação a responsabilidade delitual, a regra é do local do dano ou do domicílio do Réu, com atenção para exceções previstas em lei, por exemplo: acidente de trânsito; 
h) Prescrição: salvo disposições em lei, o prazo para responsabilizar a parte infratora no contrato é de 10 anos (Art. 205/CC). Em contraposição o prazo para reparação de dano em razão de um ato ilícito é de 3 anos (Art. 206, § $3^{\circ}$, inc. V/CC);

O Superior Tribunal de Justiça, ao julgar o Recurso Especial n ${ }^{\circ}$. 1.281.594/SP (BRASIL, 2016), propendeu em reconhecer por unanimidade a igualdade do prazo prescricional de três anos para reparação de danos para as duas espécies de responsabilidade, seja contratual ou extracontratual, a saber:

"RECURSO ESPECIAL. PROCESSUAL CIVIL. CIVIL. AUSÊNCIA DE VIOLAÇÃO DO ART. 535 DO CPC/1973. PRESCRIÇÃO. PRETENSÃO FUNDADA EM RESPONSABILIDADE CIVIL CONTRATUAL. PRAZO TRIENAL. UNIFICAÇÃO DO PRAZO PRESCRICIONAL PARA A REPARAÇÃO CIVIL ADVINDA DE RESPONSABILIDADE CONTRATUAL E EXTRACONTRATUAL. TERMO INICIAL. PRETENSÕES INDENIZATÓRIAS DECORRENTES DO MESMO FATO GERADOR: RESCISÃO UNILATERAL DO CONTRATO. DATA CONSIDERADA PARA FINS DE CONTAGEM DO LAPSO PRESCRICIONAL TRIENAL. RECURSO IMPROVIDO.

1. $[\ldots]$

2. O termo "reparação civil", constante do art. 206, § $3^{\circ}, \mathrm{V}$, do CC/2002, deve ser interpretado de maneira ampla, alcançando tanto a responsabilidade contratual (arts. 389 a 405) como a extracontratual (arts. 927 a 954), ainda que decorrente de dano exclusivamente moral (art. 186, parte final), e o abuso de direito (art. 187). Assim, a prescrição das pretensões dessa natureza originadas sob a égide do novo paradigma do Código Civil de 2002 deve observar o prazo comum de três anos. Ficam ressalvadas as pretensões cujos prazos prescricionais estão estabelecidos em disposições legais especiais.

3. Na V Jornada de Direito Civil, do Conselho da Justiça Federal e do Superior Tribunal de Justiça, realizada em novembro de 2011, foi editado o Enunciado n. 419, segundo o qual "o prazo prescricional de três anos para a pretensão de reparação civil aplica-se tanto à responsabilidade contratual quanto à responsabilidade extracontratual".

4. Decorrendo todos os pedidos indenizatórios formulados na petição inicial da rescisão unilateral do contrato celebrado entre as partes, é da data desta rescisão que deve ser iniciada a contagem do prazo prescricional trienal.

5. Recurso especial improvido. [...]"

Para justificar a mudança de orientação, os ministros da Corte Superior de Justiça invocaram no aresto três principais fundamentos jurídicos: de ordem literal, sistemática e axiológica.

O fundamento de ordem literal, repousa na letra da lei, para afirmar que o termo "reparação civil" deve ser lido de maneira ampla, de modo a abarcar tanto a responsabilidade

Revista Brasileira de Direito Civil em Perspectiva | e-ISSN: 2526-0243| Porto Alegre | v. 4 | n. 2 |

p. 79-101 | Jul/Dez. 2018 
contratual, como a extracontratual; em segundo plano, defendeu que essa interpretação mais bem se harmoniza com as demais regras que governam a responsabilidade contratual; e, em terceiro lugar, sustentou que o princípio constitucional da isonomia impede que haja prazos distintos para as obrigações fundadas em uma e outra espécie de responsabilidade.

Os fundamentos, de ordem sistemática e axiológico, estão calcados no fato de que a sistemática adotada pelo Código Civil de 2002, foi a de redução dos prazos prescricionais, visando sobretudo a garantir a segurança e a estabilização das relações jurídicas em lapso temporal mais condizente com a dinâmica natural das situações contemporâneas, e realça que nas relações de consumo, que também é derivada de relação contratual, sobretudo com a presença de parte vulnerável, o prazo editado pelo legislador foi de cinco anos, não sobejando razões para adoção do prazo geral de dez anos, que configura-se demasiadamente extenso.

Judith Martins-Costa e Cristiano de Sousa Zanetti (2017, parte 1), destacam que ao longo de um decênio, de maneira majoritária, o Superior Tribunal de Justiça concluiu que a pretensão indenizatória fundada na responsabilidade contratual estava sujeita à prescrição de dez anos, vez que foram proferidos 22 acórdãos nesse sentido contra apenas quatro em sentido oposto, que reconheceram o prazo prescricional de três anos.

Contudo, a solidificação deste entendimento foi quebrada com o julgamento do Recurso Especial no. 1.281.594/SP.

Na percepção dos autores, a interpretação realizada pelo Superior Tribunal de Justiça põe em xeque a unidade lógica do Código, pois é equivocada a correlação da expressão "reparação civil" com "inadimplemento contratual", "incumprimento" ou "inexecução contratual", como se fossem sinônimos. Não é coerente utilizar a expressão "reparação civil" de modo indiscriminado, pois esta somente é referenciada no título IX, do Livro I, da Parte Especial, dedicado à "responsabilidade civil", ou seja, primariamente, à responsabilidade extracontratual, não guardando qualquer pertinência com o tema de contratos. (MARTINSCOSTA; ZANETTI, 2017, parte 2)

Argumentam ainda, que as relações embasadas em um negócio jurídico, ademais, podem se estender longamente no tempo, gerando, em razão de sua duração, um grau de pessoalidade no vínculo e uma confiança qualificada entre as partes, situação esta, que difere

Revista Brasileira de Direito Civil em Perspectiva | e-ISSN: 2526-0243| Porto Alegre | v. 4 | n. 2

p. $79-101$ | Jul/Dez. 2018 
do "contato entre vítima e lesante, ademais, surgindo com o dano e em razão do dano, esvaise tão logo a reparação tenha lugar". (MARTINS-COSTA; ZANETTI, 2017, parte 4)

O Superior Tribunal de Justiça consignou ainda que, um mesmo inadimplemento contratual, pode resultar na aplicação de diferentes prazos prescricionais, sendo o prazo trienal para se ajuizar Ação de Indenização e do prazo decenal para manejar Ação de Obrigação de Fazer ou Ação de Execução. A Corte Superior também consignou que deve ser resguardado o prazo de cinco anos para mover Ação de Cobrança de Dívida Líquida, com base no artigo 206, $\S 5^{\circ}$, inciso I, do Código Civil (2002), eis que há previsão específica para esta situação.

Apesar do intensa fundamentação exposta no referido acórdão da Corte Superior, o julgado exterioriza algumas incoerências, ao supor que: passados três anos, o devedor poderia, assim, obter o efeito equivalente à purgação da mora sem, todavia, ressarcir os prejuízos causados ao credor, o que contrastaria com a regra constante do artigo 401, inciso I, do Código Civil. (MARTINS-COSTA; ZANETTI, 2017, parte 3)

A mesma prospecção se verifica na hipótese de inadimplemento definitivo, situação em que o credor teria então dez anos para pleitear a execução pelo equivalente ou, se cabível, a resolução, mas apenas três para reclamar o pagamento das perdas e danos decorrentes do inadimplemento.

Neste sentido, teria havido maior coerência se o julgado resguardasse o mesmo prazo para que o credor pudesse exercer quaisquer das três pretensões que a lei põe à sua disposição para reagir diante do inadimplemento.

A decisão comentada registra ainda que não é voz isolada e que possui respaldo na doutrina, ainda que minoritária, tais como: Yussef Said Cahali, Rui Stoco, Gustavo Tepedino; e não nega a existência de posicionamento contrário e majoritário, tais como: Humberto Theodoro Jr., Álvaro Villaça Azevedo, Gisela Sampaio da Cruz, Judith Martins-Costa, Washington de Barros Monteiro.

\subsection{TEORIA ECLÉTICA}

Revista Brasileira de Direito Civil em Perspectiva | e-ISSN: 2526-0243| Porto Alegre | v. 4 | n. 2 |

p. 79-101 | Jul/Dez. 2018 
Os professores espanhóis Mario Castilho Freyre e Verónica Rosas Berastain (2014, p. 54) defendem ainda a existência de uma terceira teoria, denominada de Teoria Eclética, sob o ponto de vista de que os irmãos Henri Mazeaud e León Mazeaud sintetizaram as teses dualista e monista e criaram uma terceira teoria chamada eclética. $\mathrm{O}$ fundamento para a existência de uma terceira teoria, se dá pelo fato de:

"[...] la tesis ecléctica, si bien reconece y mantiene la existencia de dos campos diversos (el contractual y el extracontractual), asevera que las diferencias que existen entre uno y otro resultan ser accesorias y se encuentran determinadas, en verdad, por una disímil y separada regulación legislativa."

Os estudiosos adeptos desta teoria, vislumbram que atualmente não há discussão acerca da dualidade do conceito de culpa, pois a percebem como sendo única, e que as diferenças entre as responsabilidades contratual e extracontratual, são mantidas primordialmente pela regulação legislativa e pelos acessórios de cada instituto.

Também esboçam um raciocínio similar os professores argentinos Amézega e Mosset Iturraspe (apud Freyre; Berastain; 2014, p. 54), pois existe uma unidade genérica que tem como centro a culpa entendida como fato humano imputável em que ambos se produz uma violação de um vínculo jurídico.

Os professores espanhóis apontam ainda que Yzquierdo Tolsada (apud Freyre; Berastain; 2014, p. 54) propugna uma unificação moderada, com base em 3 razões: 1 Ordem Substancial: há necessidade de se indenizar o credor/vítima; 2 - Ordem Sistemática: A distinção de regimes pode criar a falsa apreciação de que possuem elementos estruturais comuns, pois a linguagem utilizada - Responsabilidade Contratual dá ideia de violação e não de responsabilidade; 3 - Ordem prática: que determinados casos similares possam ser decididos pelos tribunais de forma diversa;

Conseguintemente, é possível concluir que esta terceira categoria de classificação, propugna algo semelhante com a tese monista, ou seja, são adeptos a unificação das responsabilidades, contudo, sob o prisma da construção de um novo regime jurídico, e não simplesmente pela absorção da responsabilidade contratual pela delitual.

A título de exemplo, explica Domini (2004, p. 8), que o Código Civil alemão - BGB, não prevê diferença ou separação entre obrigações contratuais e extracontratuais, vez que lhe

Revista Brasileira de Direito Civil em Perspectiva | e-ISSN: 2526-0243| Porto Alegre | v. 4 | n. 2 |

p. 79-101 | Jul/Dez. 2018 
foi dado o mesmo tratamento jurídico, e que apresente inovação resultou na evolução no direito obrigacional. Comenta o autor que as obrigações tem origem nos Negócios Jurídicos ou nos Fatos Jurídicos, inexistindo um critério de especificação das obrigações.

\section{CONCLUSÃO}

É evidente a existência acessória de cada instituto de responsabilidade, da mesma forma que é irrefutável a tese de que há uma similitude do fato gerador de ambas responsabilidades, seja pelo contato social ou pela transgressão de uma obrigação, seja esta obrigação oriunda da lei ou de uma convenção estabelecida entre as partes, e que se prestam a uma mesma finalidade.

No Código Civil brasileiro a dicotomia entre responsabilidade contratual e extracontratual é tradicional, o que evidencia suas diferenças de forma irrefutável. Logo seu reflexo na disciplina de prescrição deveria, assim, ser respeitado.

Verifica-se que no Código de Defesa do Consumidor a unicidade das responsabilidades reflete benefícios para sociedade e para os operadores do direito, o que demonstra a perfeita possibilidade de unificação de ambos institutos.

Também se faz necessário reconhecer que atualmente a discussão acerca da dualidade do conceito de culpa, que no passado constituía como principal motivo para que não se acolhesse a tese monista, perdeu força em razão da responsabilidade erigida com base na culpa in contrahendo ou pré-contratual tanto pela doutrina ou pela jurisprudência pátria.

Mostra-se necessária mover a névoa que ofusca em qual modalidade de responsabilidade se enquadra a caracterização da culpa in contrahendo ou pré-contratual.

A partir da concepção da Teoria Monista e Eclética, os estudiosos do direito civil reconhecem a possibilidade de se sintetizar as responsabilidades contratual e extracontratual, para criação de um modelo novo de responsabilidade, despido de seus princípios regentes e desvinculados de seus preceitos existentes, tais como: noção de culpa, nexo de causalidade. Deste modo o legislador estaria imbuído de forjar um novo modelo de responsabilidade, como por exemplo, fora criado de forma específica e eficiente para o Código de Defesa do Consumidor. 
Não se trata de resolver o problema de forma simples, deslocando o sistema da responsabilidade contratual para o sistema de responsabilidade extracontratual, o qual é considerado mais robusto e mais completo. Também não se trata de adaptar a responsabilidade contratual para os moldes congêneres da responsabilidade delitual, razão pela qual as premissas que embasam a responsabilidade civil teriam de ser esquecidas, para dar lugar a um modelo imaculado e único de responsabilidade civil.

Embora notória a tendência de unificação de regimes, pois é um tema em voga em praticamente todos os manuais de direito civil, também é escasso o material que se proponha a embater os problemas de forma robusta a se permitir as primeiras respostas acerca da possibilidade de transposição da barreira dogmática, de qual tese se mostra mais viável.

\section{REFERÊNCIAS}

AGUIAR JÚNIOR, Ruy Rosado de. Extinção do contrato por incumprimento do devedor. Rio de Janeiro: Aide, 1991.

AZEVEDO, Antônio Junqueira de. Responsabilidade pré-contratual no Código de Defesa do Consumidor: estudo comparativo com a responsabilidade pré-contratual no direito comum. Disponível em: <http://www.revistas.usp.br/rfdusp/article/view/67292>. Acesso em: 15 jun. 2017.

BRASIL. Código Civil. Lei $\mathbf{n}^{\circ} \mathbf{1 0 . 4 0 6}$, de 10 de janeiro de 2002. Disponível em: <http://www.planalto.gov.br/ccivil_03/leis/2002/L10406.htm>. Acesso em: 28 jun. 2017.

BRASIL. Lei $\mathbf{n}^{\circ}$. 8.078, de 11 de setembro de 1990. Disponível em: <http://www.planalto.gov.br/ccivil_03/leis/L8078.htm>. Acesso em: 29 jun. 2017.

BRASIL. Superior Tribunal de Justiça. Recurso Especial $n^{\circ}$ 1367955. Relator: Paulo de Tarso Sanseverino. São Paulo, SP, 18 de março de 2014. Disponível em: $<$ https://ww2.stj.jus.br/processo/revista/documento/mediado/?componente=ITA\&sequencial= $1305705 \&$ num_registro $=201102623917 \&$ data $=20140324 \&$ formato $=P D F>$. Acesso em: 16 abr. 2015.

BRASIL. Superior Tribunal de Justiça. Recurso Especial n*. 1.281.594/SP. Os Ministros Nancy Andrighi, Paulo de Tarso Sanseverino e Ricardo Villas Bôas Cueva votaram com o Ministro Relator Marco Aurélio Bellizze. Recorrente: Buchalla Veículos Ltda. Recorrido: Ford Motor Company Brasil Ltda. Julgado em 22/11/2016.

Revista Brasileira de Direito Civil em Perspectiva | e-ISSN: 2526-0243| Porto Alegre | v. 4 | n. 2 |

p. 79-101 | Jul/Dez. 2018 
BRASIL. Câmara dos Deputados. Projeto de Lei $\mathbf{n}^{\mathbf{0}}$ 6960/2002. Disponível em: <http://www.camara.gov.br/proposicoesWeb/fichadetramitacao?idProposicao=56549>.

Acesso em: 29 jun. 2017.

BECKER, Anelise. Elementos para uma teoria unitária da responsabilidade civil. In: JÚNIOR, Nelson Nery; NERY, Rosa Maria de Andrade. Responsabilidade Civil: Teoria Geral. São Paulo: Revista dos Tribunais, 2010.

CARVALHO, José Mauricio de. A teoria tridimensional do Direito de Miguel Reale. Revista Estudos Filosóficos. n. 14/2015. Versão eletrônica. ISSN 2177-2967. DFIME - UFSJ, São João del-Rei/MG, Pág. $201 \quad$ 212. Disponível em: <http://www.ufsj.edu.br/revistaestudosfilosoficos>. Acesso em: 25 jun. 2017.

CASIELLO, Juan José. Sobre la unificación de los regímenes de responsabilidad civil. Revista Argentina La Ley. 1989, p. 912.

CONSELHO DA JUSTIÇA FEDERAL. I Jornada de Direito Civil. Enunciado 24. Disponível em: <http://www.cjf.jus.br/enunciados/>. Acesso em: 25 jun. 2017.

DINIZ, Maria Helena. Curso de direito civil brasileiro. Teoria das obrigações contratuais e extracontratuais. V. 3, $28^{\mathrm{a}}$ ed., São Paulo: Saraiva, 2012.

DOMINI, Rogério Ferraz. Responsabilidade Civil Pós Contratual: no novo código civil e no código de defesa do consumidor. $3^{\text {a }}$ ed. São Paulo: Saraiva, 2004.

FREYRE, Mario Castillo; BERASTAIN, Verônica Rosas. La Atomización de La Responsabilidad Civil: (O como el mundo moderno ha desechado la unificación de la responsabilidad civil). Bogotá: Universidad Libre, 2014.

JACOB, Vera. Revista de Informação Legislativa. Brasília a. 34 n. 136 out./dez. 1997. Dano pré-contratual: uma análise comparativa a partir de três sistemas jurídicos, o continental europeu, o latino-americano e o americano do norte. Palestra proferida no Congresso de Daños. Buenos Aires, 24 a 26 de abril de 1997. Disponível em: <http://www2.senado.leg.br/bdsf/item/id/303>. Acesso em: 17 jun. 2017.

MARTINS-COSTA, Judith; ZANETTI, Cristiano de Sousa. CONJUR. Qual é o prazo prescricional da responsabilidade contratual? Parte 1, 2, 3 e 4. Disponível em: <http://www.conjur.com.br/2017-mai-29/direito-civil-atual-prazo-prescricionalresponsabilidade-contratual-parte\#_ftn7>. Acesso: 20 jun. 2017.

MENEZES CORDEIRO, Antônio Manuel da Rocha e. Tratado de Direito Civil Português. I, Parte Geral, Tomo I, $2^{\text {a }}$ ed., Almedina, 2000.

PONTES DE MIRANDA, Francisco Cavalcanti. Tratado de Direito Privado. Rio de Janeiro: Borsoi, 1966, tomo LIII.

Revista Brasileira de Direito Civil em Perspectiva | e-ISSN: 2526-0243| Porto Alegre | v. 4 | n. 2 |

p. 79-101 | Jul/Dez. 2018 
POPP, Carlyle. A responsabilidade civil pré-negocial: o rompimento das tratativas. Curitiba: Juruá, 2001.

PEREIRA, Régis Fichtner. A responsabilidade civil pré-contratual: teoria geral e responsabilidade pela ruptura das negociações. Rio de Janeiro: Renovar, 2001.

RIO GRANDE DO SUL. Tribunal de Justiça. Apelação Cível no. 591028295. Relator: Des. Ruy Rosado de Aguiar Júnior. De Canguçu/RS. Julgado em: 06 de janeiro de 1991.

SAVAUX, Eric. O fim da responsabilidade contratual? Tradução de J. Dantas de Oliveira. Revista Justitia, São Paulo, v. 63, n. 194, abr/jun 2001, p. 130. Publicado na "Révue Trimestrielle de Droit Civil”, 1999, no 1 (janeiro-março), Éditions Dalloz, Paris, Disponível em: <http://www.revistajustitia.com.br/artigos/209c5b.pdf>. Acesso em: 06 mai. 2017.

SILVA, Américo Luís Martins da. O Dano Moral e a sua Reparação Civil. $3^{\mathrm{a}}$ ed. São Paulo: Revista dos Tribunais, 2005.

SOARES, Renata Domingues Balbino Munhoz. A boa-fé objetiva nas fases contratuais. Revista Justitia. Disponível em: <http://www.revistajustitia.com.br/artigos/7zz15z.pdf>. Acesso em: 05 mai. 2017.

STOCO, Rui. Tratado de responsabilidade civil: doutrina e jurisprudência. $8^{a}$ ed. São Paulo: Revista dos Tribunais, 2011. 